\title{
Growth and its Discontents: Charting inclusive pathways for economic growth
}

\author{
ARTHUR MULIRO \\ WAPAKALA AND \\ AIDAN EYAKUZE
}

\begin{abstract}
Is Africa necessarily doomed to suffer the ill effects of a clash between labour and capital? Are the perverse effects of the growth of the continent's economies inevitable or avoidable? Perhaps these phenomena only become self-fulfilling prophecies to the extent that the continent's leadership does not embed sufficient foresight in its planning function to address the shortcomings that will accompany the economic growth cycle. Arthur Muliro Wapakala and Aidan Eyakuze provide some examples from the Society for International Development's (SID's) work in East Africa of how foresight can be used to generate conversations that narrow the gap between the various stakeholders in the development process and help in building a common understanding of the opportunities and challenges that need to be tackled jointly.
\end{abstract}

KEYWORDS Africa; economic growth; future; foresight; leadership; uncertainty

\section{Introduction}

The phenomenal growth rates being recorded by African economies have given cause to a new euphoria about the possibilities and prospects for this continent, until recently written off by most observers. While the promise of this growth is exciting and offers new opportunities to remedy many of the shortcomings that have dogged postindependence Africa, it is nonetheless worth noting that much still remains to be done in order to ensure that the fruits of this growth are better distributed within the population. In particular, the phenomenon of 'jobless growth' and the risk of a potential backlash by those excluded from the benefits of this growth have been tackled by some of the authors in this journal collection. Indeed it would appear that most governments are content to focus attention on the growth aspect and to gloss over the increasing tensions that are emerging with a rapid expansion in conspicuous consumption by the middle class. The magic of this operation, it seems, is to seduce the population by suggesting that if they are sufficiently patient, then the fruits of the growth will eventually trickle down to them.

At a recent Africa Development Forum organized by the School of Oriental and African Studies, Patricia Daley asked who is really benefiting from Africa's growth. Although Africa's growth pattern shows signs of broadening, in general the sectors 


\section{Wapakala and Eyakuze: Inclusive Growth}

driving growth are more capital-intensive than labour-intensive, propelling foreign direct investment into highly corporatized areas. This does little to help those underemployed and surviving on precarious, informal work without social protection. $^{1}$

Mthuli Ncube, Chief Economist at the African Development Bank, speaking at the launch of the 2012 Africa Economic Outlook report said: "The continent is experiencing jobless growth. That is an unacceptable reality on a continent with such an impressive pool of youth, talent and creativity'.2

There are signs that the blue-collar workers and white-collar professionals who are either unable to partake of the gains of this growth or feel that they are being short-changed are increasingly impatient and disillusioned. In South Africa, the recent violence at the Lonmin mines that left 34 miners dead was perhaps a stark indication that much is rotten beneath the surface. Indeed, that the miners grievances had not received much attention to hitherto is also perhaps an indication of the indifference to which much of the middleclass and national leadership treats the question of growing dissatisfaction with the current growth story. The Lonmin debacle was perhaps the tip of the iceberg - labour unrest in South Africa is spreading to other sectors and it is expected that should it continue, it would take a significant toll on the country's exchange rate and efforts to attract foreign investment. A quick scan of some of the buried headlines in Africa's press will also indicate that there is growing industrial unrest in several other African countries - in Namibia, where looming strikes face the mining and manufacturing sector, ostensibly fuelled by 'growing inequality'3 Strikes by professional workers in Ghana, Zambia, Tanzania, Kenya, Cote d'Ivoire, as well as a growing resentment of foreign investors, particularly in those countries with an extractive industry sector, all indicate that there is increased pressure on governments to top up wages in order to appease the striking workers. What is also interesting is that in virtually all of these cases, governments have taken a hardline approach in dealing with these cases of industrial action. The increasing belliger- ence of the working classes is a clear indication that the romantic attraction of economic growth has lost its lustre for the vast majority of Africans.

In his book, Nations and Nationalism, Ernest Gellner wrote about the 'social bribery fund' whereby industrial society used the promise of material gain and enhancement to buy off social aggression. Gellner remarked that such societies were usually successful in their appeasement until the flow of resources faltered, leading to a 'loss of legitimacy' characterized by episodes of violence. While most African societies are far from industrialized, this analogy can be applied as it is perhaps not by chance that as the financial crisis deepens in the richer nations of the North, there is also an increased reluctance by governments in the South to invest more on wages and other social sectors given reductions in aid flows and the general climate of global economic uncertainty.

But is Africa necessarily doomed to suffer the ill effects of a clash between labour and capital? Are the perverse effects of the growth of the continent's economies inevitable or avoidable? Perhaps these phenomena only become self-fulfilling prophecies to the extent that the leadership does not embed sufficient foresight in its planning function to address the shortcomings that will accompany the economic growth cycle. It might be that the questions of inequality have been given a lower priority or it was assumed that there would be sufficient trickle-down to address some of the 'inefficiencies' of the growth. Still, and perhaps on account of Africa's particular development situation, it is necessary to factor in questions on how to maximize the benefits of this growth for the majority of the population. The key difference is that this growth is happening at a period when the effects of education, technology (particularly the Internet and mobile telephony) and ease of mobility are reducing the relative isolation of the continent. People might still be in the rural areas, but they are not cut off from the goings on in the rest of the world. They are able to appreciate (if not understand) the transitions taking place around them and they are eager to be part of the good news story.

The need to pay attention and greater emphasis to the growing questions of inequality and 
deepening poverty within a panorama of expanding wealth is perhaps one that does not elicit a lot of excitement, but paradoxically, continued growth is dependent on securing a bargain to address these issues while at the same time expanding opportunities for economic growth. Two critical elements stand out in this regard: first, the youthful content of the African population - to the extent that Africa's youth continue to feel alienated from the change processes taking place on the continent, they will continue to be a source of tension and potential problems. As such, finding ways and means - although not easier said than done - of creating meaningful opportunities for employment for them is important. This is a longer-term process that calls for sustained partnerships between government and industry and also in terms of rethinking education curricula to cater for the structural changes taking place in the economy. Second, and not any less important, is the need to rethink the nature of the state and renegotiate the social contract between citizen and state. The majority of African states are implicit extensions of the extractive colonial state that preceded them. They did not renegotiate or invest in explaining to their citizens the nature of the relationship between them. This explains to a significant extent, the existence of the 'strong' state in Africa whose legitimacy has relied on the presence of 'strong men', the (at times excessive) use of force and outright bribery to purchase loyalty. Two countries that have negotiated fairly progressive constitutions with Bills of Rights - South Africa and Kenya, have codified this relationship in different terms and it could be instructive to see how the state copes with the new demands that are thrust upon it.

In recent years, there has been a reversion to technocratic approaches to casting a path into the future. The plethora of national vision exercises, while admirable in their efforts to try and generate alignment towards a desired future are also largely open to criticism in that they have by and large failed to take into account some of the deeper drivers shaping society and assume that the trajectory to be pursued is a constant - simply doing more of what has been done in the past, but
Visions, by their very nature embody a series of assumptions about how the world is likely to evolve and to the extent that these assumptions are not shared broadly within the population or the outcome of conversations that seek to engage as many stakeholders as possible, it is highly probable that the visions will not capture the aspirations of the majority, but rather a segment of the total population.

As such, and in light of the challenges emerging from the limits of the growth model, many of which are not explicitly catered for in the vision paths and trajectories, it is necessary to bolster the 'toolkit' available to policy actors to enable them to anticipate some of the bottlenecks that will have to be navigated if the eventual visions are to be kept current and responsive to a changing environment.

\section{Africa's future ain't what it used to be! - The case for foresight and insight}

Clearly, the growth that the region is experiencing today is in many respects casting the possibility for a new future that will be different from anything that has been experienced in the past and perhaps also insofar as the human experience goes, unprecedented. In the decades ahead, Africa will be more populous, more urbanized, wealthier and more unequal and more sought after by a hungry world.

Successfully navigating that future will require much deeper understanding of the drivers shaping the visible and invisible changes, many of which are revealed through careful gathering, analysis and combining of data. Such evidencebased insight will counteract the more prevalent practice of perception-based discourse about the continent's current state, context and prospects. Sadly, the capacity for robust, reliable data gathering and analysis is in short supply across Africa.

Two institutions acknowledge this fact. The Economic Commission for Africa lamented the lack of seriousness by African governments in gathering employment data. The UN Economic Commission for Africa/African Union Economic Report on Africa 2010 on the theme 'Promoting 


\section{Wapakala and Eyakuze: Inclusive Growth}

high-level sustainable growth to reduce unemployment in Africa' observed that since the mid1990s, "the majority of African countries have abandoned the holding of annual employment and earnings surveys' and noted that it was 'essential to future development policy in Africa that governments should give priority to the collection of data on employment. ${ }^{4}$ More recently, the 2012 edition of the Ibrahim Index of African Governance continues to advocate addressing the paucity of African data and the need for statistical autonomy within African countries. This is a leadership and governance issue. One of Africa's biggest challenges going forward is to master its own robust statistical system. Political sovereignty begins with data autonomy.

The Society for International Development's (SID's) own experience with the State of East Africa Report series highlights the tremendous value of data compilation, analysis and presentation for strategic decision making. These reports have four main objectives. The first is to provide factual information about different social, political, cultural economic and technological transitions taking place in East Africa in a way that is easily accessible to decision makers and citizens. Second, they provide insight on what the data means for the region by interrogating and exploring the forces that generate them. Third, they aim to spark the imagination by catalyzing new thinking about how the various forces might be shaping the future. Finally, the reports encourage deeper engagement by citizens with the formal and informal processes that influence the direction that society is taking.

The report has been very well received and it has sparked a series of conversations about regional integration. Since the report's launch in April 2012, SID has been invited to 13 public and strategic encounters within the EAC. As of October 2012, SID has distributed 3,000 printed reports, the section on the SID Website has been visited over 255,000 times since the launch and more than 5,000 copies of the report downloaded. The reach of this report has also been exemplified by the wide variety of appearances in national, regional and global press and media outlets. At the time of this writing, the State of East Africa Report
2012 had garnered 41 mentions in press and media outlets.

\section{Foresight}

An article in the 20 October 2012 issues of The Economist quotes a World Bank economist cheerily stating that if current trends continue, most of Africa will be middle-income by $2025^{, 6}$. While this is encouragingly optimistic, the caveat implied by the 'if' word is important. It allows for uncertainty and the possibility of surprises that occur more often than is usually admitted, and that have significant impact on the trajectory of Africa's communities, nations and regions. This is where good foresight and scenario-building exercises are such valuable tools of 'future-proofing' current (national) development plans and corporate strategies.

Such foresight is in short supply and, with the exception of the South African Presidency, is rarely used in African public policymaking. In an effort to ground the discourse about the trajectory being taken by various African countries, public interest scenarios were developed for Kenya, Uganda and Tanzania individually, and for the East African region. Having correctly imagined, almost a decade earlier, the possibility of Kenya's 2007-2008 post-election violence in the El Nino story of the 'Kenya at the Crossroads' scenarios project (IEA/SID, 2000), scenario-building has slowly begun to be taken more seriously by Kenya's senior civil servants. The overarching question asked in the 'Tutafika Tanzania' scenarios (SID, 2003) - Who are we? Where are we going? are taking on an ominous urgency as politics, religion and Zanzibari nationalism combined in a combustible mix by October 2012. The tribulations currently rocking Nigeria's North and oilrich South were imagined in the 'Jaga Jaga Republic' story of the Naija2025 scenarios which were commissioned by the Africa Leadership Institute and launched in 2008. These largely negative possibilities were universally dismissed out of hand by most of the government and business decision makers who came across them. It was too difficult for them to imagine that things could fall apart so rapidly and so completely. The world is only par- 
tially 'makeable' so the current discourse about Africa's future could benefit from some creative thinking and a departure from the attractive but often misleading temptation to think in a linear fashion.

What is critical about the application of these tools is not so much their 'predictive' capabilities, but their power in helping to facilitate critical conversations that can assist leaders and leadership understand the needs of the citizenry and to respond to them. They are also helpful in empowering the general public, broadening their understanding of the critical forces at play in the system and how they can contribute - positively - to attain commonly held goals. What has been lacking in the rush to ensure economic growth was a conversation about what was necessary to adopt and/or sacrifice. Now that the growth is happening, it is perhaps not too late to engage in a broad-based conversation to understand how to make it work for all Africans. To do so calls for a deeper understanding of the aspirations of all Africans - rich and poor; urban and rural; male and female; young and old. Only by beginning to share collective hopes and fears can a complex tapestry of shared goals be woven and a broad commitment to work together to achieve these goals forged. The first steps call for humility and understanding on the part of the leadership and the ability to appreciate that unless the fruits of success are accessible to all, the harvest might well end up being a bitter one.

In her review of Chinua Achebe's book There was a Country: A Personal History of Biafra, Chimamanda Adichie quotes an earlier Achebe essay, The Novelist as Teacher, in which 'the writer', he says, is often faced with two choices - turn away from the reality of life's intimidating complexity or conquer its mystery by battling with it? ${ }^{7}$ Those entrusted with the responsibility of shaping Africas future are faced with exactly the same intellectual and practical choices. Those who elect to do battle with continent's 'intimidating complexity' could do with equipping themselves with as many facts as possible and a robust sense of foresight.

\section{Notes}

$1 \mathrm{http} / /$ allafrica.com/stories/201207190370.html.

2 http://www.guardian.co.uk/global-development/2012/may/28/african-economic-outlook-2012-youth-unemployment.

3 http://allafrica.com/stories/201209181011.html.

$4 \mathrm{http}: / /$ www.sidint.net/docs/RF07.july\%202010.pdf.

5 http://www.moibrahimfoundation.org/downloads/2012-IIAG-summary-report.pdf.

6 http://www.economist.com/news/middle-east-and-africa/21564856-boom-sub-saharan-africa-attracting-business-talent-rich-world.

7 http://www.lrb.co.uk/v34/n19/chimamanda-adichie/things-left-unsaid.

\section{References}

Institute of Economic Affairs and Society for International Development (2000) 'Kenya at the Crossroads - Scenarios for Our Future', available at www.kenyascenarios.org/pdf/scenarios.pdf.

Society for International Development (2003) ‘Tutafika Tanzania - Imagining our Future’. 